\title{
Optimizing Sugar Recovery in India: Need for an Integrated Approach
}

\section{Roy* and Amaresh Chandra}

Indian Institute of Sugarcane Research, Lucknow, India

*Corresponding Author: MM Roy, Indian Institute of Sugarcane Research, Lucknow, India. E-mail: mmroyster@gmail.com

Orcid ID: http://orcid.org/0000-0003-4325-3713

DOI: 10.31080/ASAG.2020.04.0806
Received: February 08, 2020

Published: February 19, 2020

(C) All rights are reserved by MM Roy and

Amaresh Chandra.

\begin{abstract}
Growing demands and little scope of expanding the area under sugarcane in India necessitates improvement in the scenario of sugar recovery in addition to rise in crop productivity. The sugar recovery rates in the country are low when compared to many other sugar growing countries. After harvest the crop loses its sugar content rapidly during storage, transport and processing. The scenario of five major sugarcane growing states (accounting about 85 per cent of sugar production) viz., Andhra Pradesh, Karnataka, Tamil Nadu, Maharashtra, Uttar Pradesh is analysed and state specific strategies are outlined for optimizing sugar recovery.

Significance' Statement: The paper analyses the sugar recovery (that is less than international standards) situation in 5 major sugar producing states of India, State specific strategies are derived for improving the situation in the country.
\end{abstract}

Keywords: Crushing Schedule; Inversion; Mill Management; Stale Cane; Sour Cane; Varietal Balance

\section{Introduction}

India is the second largest producer of sugar just after Brazil. This sector faces several constraints viz., low cane yields, short crushing season, supply of stale canes, rising production costs, fluctuating trends in production, size of mill and its inefficient machinery, low recovery rates etc. In this paper issues related to low recovery of sugar is highlighted and solutions are suggested for its optimization. When compared to the international scenario, sucrose content of Indian cane is more or less same but the realized rate of sugar recovery is low, only around $10-10.5$ per cent. The average recoveries in other countries like Brazil, Mexico, South Africa and Thailand are 14.6, 13.5, 12.2, 12.1 and 11.3 per cent, respectively [1-3].

Accumulation of sugar in the crop represents a balance between synthesis of sugar and its utilization. Soon after harvest, decline in its sugar content starts and staling beyond 24 hours results in reduction in cane weight on account of moisture loss and decline in juice sucrose content due to inversion. After 96 hours, the loss in cane weight and sugar recovery is as high as 7.5 to 17 per cent and up to 2 per cent, respectively. This leads to mill and boiling capacities adversely and also increased loss of sugars in molasses $[4,5]$. Glucose polymers namely dextran formed in the process have significant negative influence in processing efficiency of mills [6].

Under normal milling conditions sugar loss is estimated to be around 1.0 to $2.5 \mathrm{~kg}$ of sucrose per ton of cane ground between crusher juice and mixed juice depending on the factory conditions. About 13 per cent of this loss (crushing of stale cane) is due to chemical inversion, 25 per cent is due to the activity of cell free enzymes and about 62 per cent is eaten up by the microorganism present in juice and mills. Therefore, proper mill sanitation use of effective biocide is important to enhance processing efficiency and sucrose recovery. The extent of loss in Indian sugar mills is reported about 5 to 10 kilogram sugar per ton of cane ground, may be even more when crushing is extended in summer months $[3,6]$.

The acreage of sugarcane increased by 13.48 per cent from 2000-01 (4.32 million ha) to 2017-18 (4.97 m ha). However, about 85 per cent of production in country comes from 5 states 
viz., Andhra Pradesh, Karnataka, Tamil Nadu, Maharashtra, Uttar Pradesh. In this paper the present scenario of sugar recovery in five major states of the country is analysed and the need for state specific focus is highlighted with a view to realize better sugar recovery.

\section{Materials and Methods}

The data on sugar recovery achieved in India during 2002-2003 to 2016-2017 were collected for 5 states viz., Maharashtra, Uttar Pradesh, Tamil Nadu, Karnataka and Andhra Pradesh and average for whole country. The available literature on reasons of sugar recovery losses and management was scanned and compiled. The strategy for improving the scenario through a state specific approach was worked out.

\section{Results and Discussion}

\section{Post-harvest cane deterioration}

The primary cane deterioration is on account of sucrose inversion process after harvest of sugarcane and subsequent delays in delivery of cane to the sugar factory. The terms Stale cane and Sour cane are two different stages of cane deterioration after harvest. The stale cane is the aging of harvested stalks which have depleted their sucrose via continuing inversion and respiration, whereas sour cane is microbiological deterioration of sugarcane stalks by lactic acid bacterium Leuconostoc species which converts sucrose into organic acids of typical sour odour [7,8]. However, both types of deterioration seem to operate simultaneously in cane and milled juice.

The secondary losses include factory losses due to inversion, dextran, alcohol and acid formation in the extracted juice incident to inefficient and unhygienic processing [6]. The major factors that affect lead to post-harvest deterioration in sugarcane include cane variety, environment, crop ripening, biotic and abiotic stresses besides several management issues like harvest mode, transport and storage systems in mills.

\section{Regional Scenario}

On account of climatic and other factors, sugar recovery rate vary in different regions/states of the country. Sugarcane varieties play a crucial role in sugar recovery, depending upon the climate and management practices followed. Due to genetic variability different genotypes behave differently to post-harvest deterioration. The genetic nature of the variety and the morphological features viz., cane thickness, rind hardness, wax coating etc. decide the extent of post-harvest deterioration. The main sugarcane varieties used in five major sugar producing states of India is presented in table 1 [3,6,8-11].

\begin{tabular}{|c|c|c|c|c|c|}
\hline Type & Uttar Pradesh & Maharashtra & Karnataka & Andhra Pradesh & Tamil Nadu \\
\hline $\begin{array}{l}\text { Early ripening } \\
\text { varieties }\end{array}$ & $\begin{array}{c}\text { CoS 687, CoS 8436, } \\
\text { CoS 88230, CoS } \\
\text { 95435, CoSe 91232, } \\
\text { CoLk 94184, Co0238 }\end{array}$ & $\begin{array}{c}\text { Co 419, Co } 775 \text {, } \\
\text { Co } 7219, \text { CoC } \\
671\end{array}$ & $\begin{array}{l}\text { Co 6415, Co } 7704, \\
\text { CoC 671, Co } \\
85002\end{array}$ & $\begin{array}{l}\text { Co 6907, Co 7805, } \\
\text { CoT, 8201, Co 8013, } \\
\text { Co 8014, CoC 671, } \\
\text { CoOr } 03151\end{array}$ & $\begin{array}{c}\text { Coc } 671 \text {, CoC } 8001 \text {, Coc } 85061 \text {, } \\
\text { Co 7704, Co 8208, CoC 92061, } \\
\text { CoC } 90063\end{array}$ \\
\hline $\begin{array}{l}\text { Mid-season and } \\
\text { late ripening } \\
\text { varieties }\end{array}$ & $\begin{array}{c}\text { Co } 1148, \operatorname{CoS} 767, \\
\text { B0 } 91\end{array}$ & $\begin{array}{c}\text { Co } 740, \text { Co } \\
\text { 7219, CoM } \\
0265, \text { Co } 7527, \\
\text { Co } 86032\end{array}$ & $\begin{array}{c}\text { Co 62175, Co } \\
\text { 740, Co 8014, Co } \\
\text { 8021, Co 8011, Co } \\
\text { 8371, Co 7804, Co } \\
86032\end{array}$ & $\begin{array}{c}\text { Co 62175, CoA 7602, } \\
\text { Co 7219, } 85 \text { R 186, } \\
\text { Co86032 }\end{array}$ & $\begin{array}{c}\text { Co 6304, CoSi 776, CoSi } \\
\text { 86071, Co 8021, Co 85019, Co } \\
\text { 86032, Co 86010, Co 86249, } \\
\text { CoSi 95071, CoSi 96071, CoSi } \\
\text { 98071, CoG } 93076\end{array}$ \\
\hline
\end{tabular}

Table 1: Ruling sugarcane varieties (past and present) in five major sugar producing states in India.

Note: Co: Coimbatore; A: Anakapalle (AP); C: Cuddalore (TN); BO: Bihar; G: Gudiyatham (TN); KHS: Karnataka Hybrid Sugarcane; LK: Lucknow (IISR); M: Maharashtra; R: Rudrur (AP); S: Shahjahanpur (UP); Se: Seorahi (UP); Si: Sirugamani (TN); T: Tirupati (AP); Or: Orissa.

Source: Compiled from multiple sources [3,6,8,11-13].

Apart from varieties, weather is of prime importance in determining the rate of deterioration. Deleterious effects of high temperature (around $40^{\circ} \mathrm{C}$ ) and low atmospheric humidity (25 - 35\%) on juice quality are well known. Loss in commercial cane sugar (CCS) is reported highest in late-crushing period during summer (1.32 unit $\mathrm{d}^{-1}$ ) followed by mid-season crushing during spring (1.0 unit 
$\left.\mathrm{d}^{-1}\right)$ and early crushing during winter ( 0.35 unit $\left.\mathrm{d}^{-1}\right)$. Only fully mature plants should be harvested as both immature and over mature cane deteriorates faster. The time factor during transport, storage conditions, hygiene in yard, mill machinery etc. are the other considerations.

An analysis of recent sugar recovery rates achieved in five major sugar producing states of India reveals that Maharashtra and Karnataka have distinctly higher recovery rates compared to all India average. During this period peak sugar recovery has been achieved at 11.67 per cent (Maharashtra), 10.95 per cent (Karnataka), 10.65 per cent (Uttar Pradesh), 10.23 per cent in Tamil Nadu and 10.05 per cent in Andhra Pradesh. The all India average remained at 9.85 - 10.65 per cent (Figure 1).

The management

Farm level

The decades of years of research effort sat various research institutes in Indiato assess the extent of cane deterioration and contain its progress at the field have met with some success. The demonstrated technologies at various stages viz., pre-harvest, harvest and post-harvest are depicted in table 2 [4,12-17].

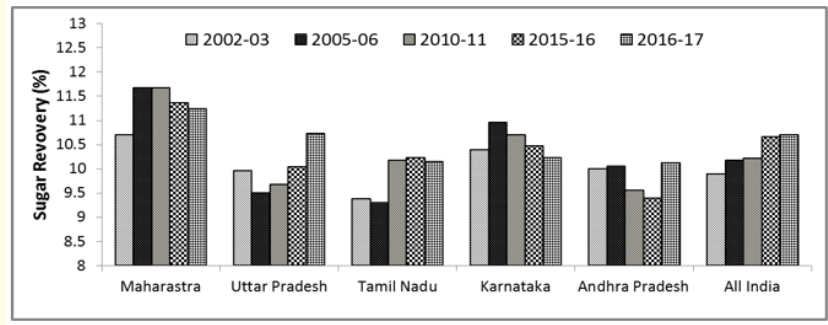

Figure 1: Recent trend of sugar recovery achieved in major sugar producing states of India.

Mill level

Several indicators viz., dextran, gum, oligosaccharides, ethanol, mannitol, reducing sugars, titrable acidity, invertase content, juice viscosity, purity drop, etc. have been identified to assess juice quality of cane arriving at the factory. Once the deteriorated cane enters the mill, a high population of viable microorganisms find entry into the extracted juice and affect upstream process by direct destruction of sucrose or converting it to other products. Use of bio-cidalagents viz., halogen compounds, ammonium bi-fluoride,

\begin{tabular}{|c|c|}
\hline Stage & Technology \\
\hline $\begin{array}{l}\text { Pre-harvest } \\
\text { management }\end{array}$ & $\begin{array}{l}\text { Pre-harvest spray of chemical ripeners (polaris, ethrel,) [14]. } \\
\text { Application of } 2 \text { per cent sodium meta-silicate ( } 3 \text { days prior to harvest) for maintaining juice quality of stored cane } \\
\text { (up to } 6 \text { days) [4]. } \\
\text { Pre-harvest spraying of mercuric chloride/cobalt chloride }\left(100 \mathrm{mg} \mathrm{l}^{-1}\right) \text { in suppressing invertase activity (up to } 20 \\
\text { days of storage) [14]. }\end{array}$ \\
\hline $\begin{array}{l}\text { Post-harvest } \\
\text { Management }\end{array}$ & $\begin{array}{l}\text { Spray of formulation containing benzalkonium chloride (BKC) + sodium meta-silicate (SMS) for improved sugar } \\
\text { recoveries (by over } 0.5 \text { units) [18]. } \\
\text { Spraying of harvested cane with benzonic acid ( } 100 \mathrm{ppm} \text { ) and formaldehyde (100 ppm) [17]. } \\
\text { Many bactericide (such as formaldehyde, Polycide, Bactrinol-100, BD Mill sanitizer, DBAC, IFOPOL, DNDT, ABF, Actin- } \\
\text { ID, potassium permanganate and sodium metasilicate, Tsunami-100, Kcide 800, Sucroguard) may be used to check } \\
\text { deterioration of cane and milled juice [18]. } \\
\text { Combined application of anti-bacterial (quaternary ammonium compounds/thiocarbamates) and anti-inversion } \\
\text { chemicals (sodium metasilicate/sodium lauryl sulphate) over freshly harvested cane followed by covering them with } \\
\text { a thick trash [19]. }\end{array}$ \\
\hline
\end{tabular}

Table 2: Technological development in managing stale cane losses in India.

(Source: Compiled from multiple sources, as indicated). 
formaldehyde, quaternary ammonium compounds (QUAT) and thio-carbamates etc. at appropriate doses and stages (first and last mill and the imbibition-maceration water) minimizes such losses effectively. The other important points are [3,5,6,18,19]:

1. Maintenance of a proper varietal balance (early, mid-late and late maturing varieties; ratoons, spring and autumn planted crop)

2. Following up of a scientific harvesting and crushing schedule based on crop/varietal maturity

3. Having a balance between daily crushing capacity and daily supplies reaching the mill

4. Cane yards are clean and follow the principle of first cane in should be first cane out.

5. Special focus on mill sanitation through an integrated approach to ensure minimum destruction of sucrose and achieve better processing efficiency.
Cane quality and post-harvest management at farm side and the efficiency of the mill on the miller side are the major factors that influence recovery rates. Potentially it can be increased from 0.4 to 0.6 per cent with efficient operations of the mill and from 1.5 to 2.0 per cent with high cane quality and appropriate post-harvest management (Figure 2).

\section{State specific approaches}

As every state has specific issues related ruling varieties, nature of variety, planting time, crop duration, agro-ecology, mill management, mill capacity and its machinery, transport arrangements, cane policy implementation at state level etc.; there are varying strengths and weakness in the context of sugar recovery that pertain to a given state [20]. The approaches should be in a direction to enhance the strengths and minimize the weakness so that gradually the sugar recovery in increased (Table 3 ).

\begin{tabular}{|c|c|c|}
\hline State & Constraints & Approaches to overcome constraints \\
\hline Maharashtra & $\begin{array}{l}\text { Irregular cane supply, high transporta- } \\
\text { tion costs, lack of technical efficiency }\end{array}$ & $\begin{array}{l}\text { Erratic cane supply to mills is corrected through appropriate harvest and } \\
\text { transport schedules. The issue of heavy handling and transport costs } \\
\text { charged by the private mills is resolved amicably. } \\
\text { Greater adoption of improved agro-practices and irrigation management } \\
\text { besides improvement in mill management, sanitation and extraction ef- } \\
\text { ficiencies }\end{array}$ \\
\hline Uttar Pradesh & $\begin{array}{l}\text { Short crushing season and crushing } \\
\text { capacity, many old mills having obsolete } \\
\text { machinery, inefficient technology, less } \\
\text { high sugar varieties, crushing of over } \\
\text { mature cane, practice of irrigating cane } \\
\text { just before harvest }\end{array}$ & $\begin{array}{l}\text { Promotion of improved sugar rich varieties, less prone to rapid deteriora- } \\
\text { tion along with appropriate agro-techniques and irrigation scheduling. } \\
\text { Well defined schedule of maturity based harvests that avoids use of over } \\
\text { stand cane } \\
\text { Improvement in mill sanitation and extraction efficiencies besides their } \\
\text { modernization. }\end{array}$ \\
\hline Tamil Nadu & $\begin{array}{l}\text { Erratic cane supplies, lack of proper } \\
\text { varietal planning, lack of technical inef- } \\
\text { ficiency }\end{array}$ & $\begin{array}{l}\text { Appropriate varietal planting and crushing schedules are strictly en- } \\
\text { forced. Good management practices, optimization of irrigation and farm } \\
\text { mechanization are adopted widely } \\
\text { Modernization drive of sugar mills with special focus on mill sanitization }\end{array}$ \\
\hline Karnataka & $\begin{array}{l}\text { Less availability of quality seeds and } \\
\text { high sugar varieties, lack of technical } \\
\text { efficiency and knowledge of cane growth } \\
\text { physiology }\end{array}$ & $\begin{array}{l}\text { Promotion of improved sugar rich varieties, less prone to rapid deteriora- } \\
\text { tion. } \\
\text { Adoption of improved agro-practices and irrigation management besides } \\
\text { emphasis on mill modernization and integrated mill sanitation }\end{array}$ \\
\hline $\begin{array}{l}\text { Andhra } \\
\text { Pradesh }\end{array}$ & $\begin{array}{l}\text { Lack of technical efficiency, lop sided } \\
\text { taxation policy in the state with respect } \\
\text { to molasses, less high sugar varieties }\end{array}$ & $\begin{array}{l}\text { Appropriate agro-techniques and irrigation scheduling. Intensive efforts } \\
\text { on identification and promotion of improved sugar rich varieties and less } \\
\text { prone to rapid deterioration. } \\
\text { Appropriate corrective measures in respect of lop sided taxation policy on } \\
\text { exporting molasses to other states. } \\
\text { Greater emphasis on mill sanitation. }\end{array}$ \\
\hline
\end{tabular}

Table 3: Approaches for minimizing sugar losses in major sugar producing states of India. 

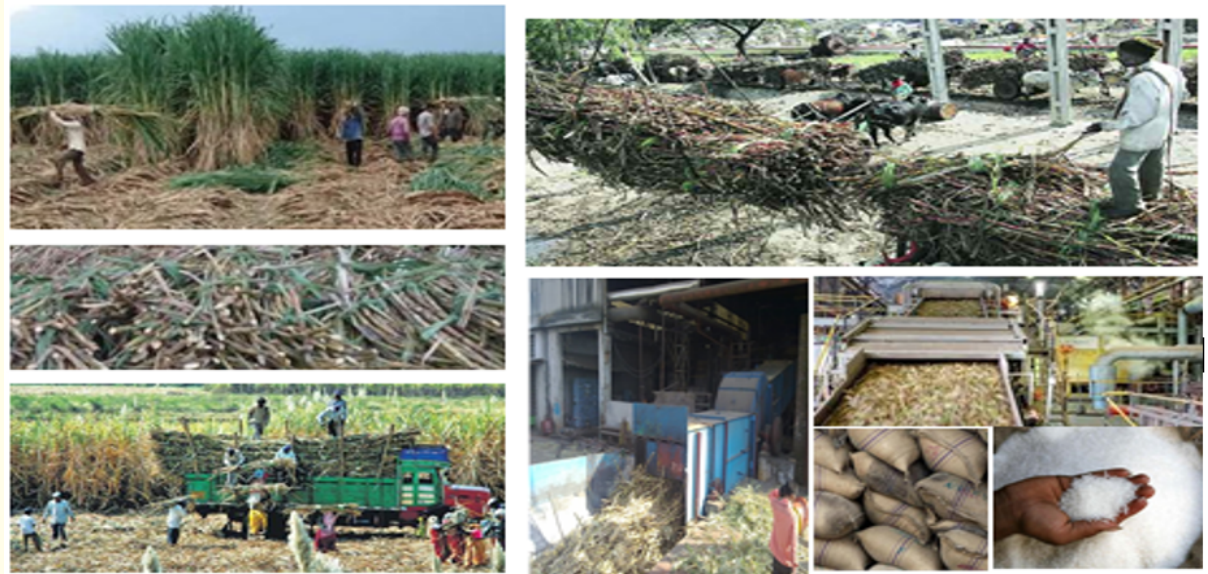

Figure 2: Scientific scheme of improved sugar recovery. Left, Harvest at maturity and rapid transport;

Right, cane yard management, mill processing and sugar production.

On account of the general misconception amongst cane growers and cane development staff that sugarcane is a weather resilient crop and there are minimal quantitative and qualitative losses after its harvest, payments to farmers based on weight of the cane (and insufficient incentive systems for higher sugar recovery) by the millers; the field (and to some extent mill) recommendations are often not practiced. It is, therefore, emphasised that an integrated strategy is devised in a given area based on local conditions and implemented with some kind of attractive incentive system so that sucrose losses are avoided to the maximum extent possible.

As the conditions differ is each state, there is a need for developing a very organized system of harvesting schedule with cane growers, transporters and millers. Care is taken that harvest is in order of ratoon crop followed by early maturing plant canes, late maturing plant canes and finally late planted canes across.Another important point is diversion of sugarcane juice for bioethanol by avoiding late crushing and less sugar recovery.

\section{Conclusion}

Improved sugar recoveries are expected to meet growing sugar demands in future with same (or even less) land area allocation for the crop in view of difficulties in expanding area on account of other pressures on cultivable land and also water availability for irrigation. Greater emphasis on developing commercial climate resistant varieties that withstand post-harvest stress in early as well as late crushing periods for specific agro-ecologies/states and following an integrated approach that overcome the losses at various stages viz., pre-harvest, harvest, post-harvest, milling procedures are, therefore, needed.

\section{Acknowledgements}

The authors are grateful to Director, Indian Institute of Sugarcane Research (IISR) and Head Plant Physiology and Biochemistry Division, IISR for facilities provided for this work.

\section{Bibliography}

1. Wright $\mathrm{T}$ and Aradhey A. "India-sugar annual - 2016". United States Department of Agriculture, Washington DC (2016).

2. KRPL. "India sugar market outlook to 2020 - Rising sugarcane svailability and government initiatives to shape the future". Ken Research Pvt Ltd, Gurgaon (Haryana) (2015).

3. KPMG. "The Indian sugar industry - Sector road map - 2017". KPMG India Pvt Ltd, Mumbai (2007).

4. Solomon S. "Post-harvest cane deterioration and its milling consequences". Sugar Tech 2 (2000): 1-18.

5. Datir S and Joshi S. "Post-harvest sugarcane quality under manual (whole cane) and mechanical (billet) harvesting". International Journal of Current Microbiology and Applied Sciences 4 (2015): 1-15. 
6. AFS. "Research report on Indian sugar industry-2013". Action Financial Services (India) Limited, Mumbai (2013).

7. Rakkiyappan P., et al. "Post-harvest deterioration of sugarcane with special reference to quality loss". Sugar Tech 11 (2009): 167-170.

8. Singh P., et al. "Deterioration of fresh and stale cane juice at high ambient temperature in relation to expression of invertases and the growth of Leuconostoc sp". Agrica 4 (2015): 7985.

9. GoI. Status paper on sugarcane. Directorate of Sugarcane Development, Ministry of Agriculture, Government of India, Lucknow (2013).

10. GoI. "Report on the working group on sugarcane productivity and sugar recovery in India. Ministry of Consumer Affairs, Food and Public Distribution". Government of India, New Delhi (2013a).

11. IISR. "Forty five years of AICRP on sugarcane". All India Coordinated Research Project (Sugarcane), Indian Institute of Sugarcane Research, Lucknow (2017).

12. Silva NDA and Caputo MM. "Ripening and the use of ripeners for better sugarcane management. In: Marin F (ed.) Crop management - cases and tools for higher yield and sustainability". INTECH, Croatia (2012).

13. Boneta-Garcia E and Lugo-Lopez MA. "Losses of sucrose in cut cane kept under shade or sun for different periods". The Journal of Agriculture of the University of Puerto Rico 46 (1962): 189-194.

14. Solomon S. "Post-harvest cane deterioration and its impact on Sugar Industry”. In: Singh SB et al. (eds) Sugarcane: Crop production and management. Studium Press LLC, Houston, Texas (USA) (2009).

15. Reddy YSK and Madhuri KVN. "Impact of delayed crush on post-harvest deterioration of promising early maturing sugarcane clones". The Bioscan 92 (2014): 519-523.

16. Kulkarni VM and Warne D. "Reduction of sugar loss due to cut to mill delay by the application of a uniquechemical composition called sucro-guard". Proc S Afr Sug Technol Ass 78 (2004): 95-102.

17. Solomon S., et al. "Post-harvest deterioration of sugarcane and chemical methods to minimize sucrose losses". Sugar Tech 8.1 (2006): 74-78.
18. Solomon S., et al. "Pre-milling sugar losses and their management in sugarcane". Technical Bulletin No.37. Indian Institute of Sugarcane Research, Lucknow (1997).

19. Desai BB., et al. "Chemical control of post-harvest losses in sugar cane". Current Research Report 1.1 (1985): 33.

20. Roy MM and Chandra A. "Technological and management options for optimizing sugar recovery in India: A review". International Journal of Engineering and Management Research 5.4 (2018): 14-22.

\section{Assets from publication with us}

- Prompt Acknowledgement after receiving the article

- Thorough Double blinded peer review

- Rapid Publication

- Issue of Publication Certificate

- High visibility of your Published work

Website: www.actascientific.com/

Submit Article: www.actascientific.com/submission.php

Email us: editor@actascientific.com

Contact us: +919182824667 